\title{
SUSTAINABILITY OF MINERAL RESOURCES IN LATVIA
}

Andrejs Lazdins ${ }^{1}$, assistant professor, Dr.oec.; Gafur Abdilakimov², assistant professor, PhD ${ }^{1}$ Latvia University of Life Sciences and Technologies; ${ }^{2}$ Tashkent State Pedagogical University Named After Nizami

Abstract. Sustainable use of mineral resources involves the interaction of economic, environmental and social processes, in which economic interests have to be adapted to the other interests. Sustainable management of mineral resources has to take into consideration the location, quality and uses of the resources. The above requires exploiting natural resources in the most efficient way so that the needs of mankind could be met in the future. The following mineral resources are extracted in all the five planning regions of Latvia: gypsum, limestone, dolomite, quartz sand, sand, gravel and clay. The quality of mineral resources is classified into categories: A mineral resource reserves, $\mathrm{N}$ - incompletely explored resources and $\mathrm{P}$ - unexplored resources have been discovered, which play an important role in defining the uses of the resources. Mineral resources are extracted and used in the construction, repairs and maintenance of roads as well as in the construction of buildings. The research problem raises a question whether the exploitation of mineral deposits or mineral resources generates economic gains and whether the extraction and consumption of mineral resources increases with an increase in the standard of living in the country. Based on this the research aim was to analyses the extraction of mineral resources in Latvia as a whole and in the planning regions of Latvia. Research results and a comparative analysis revealed that the quantity of mineral resources extracted was not strongly related to the other economic indicators, i.e. the extraction and consumption of mineral resources did not directly affect economic growth in the country. However, part of mineral resources was extracted at partly explored extraction sites, accounting for approximately $8 \%$ of the total quantity extracted. This economic activity was legal, yet it was not sustainable and did not comply with the sustainability strategies of the European Union as well as Latvia.

Key words: mineral resource, extraction, sustainability.

JEL code: Q01; Q32

\section{Introduction}

Land contributes to sustainable development and is the basis of economic activity. The characteristics of land are as follows: physical phenomena (soil, underground minerals, irrigation/drainage systems, land uses); infrastructure; the location and the environment; the ownership, use and value of land (Auzins A., 2016). Underground minerals are important as a physical phenomenon, as they are resources explored or partly explored and have some value (Lazdins A., 2016). In Latvia, the diversity of mineral resources is not broad, yet the available resources contribute to economic development and are important for manufacturing construction materials; therefore, the resources have to be exploited in a sustainable way. The key mineral resources that are extracted, processed and used are as follows: gypsum (G); limestone (L); dolomite (D); clay (C); sand (S); quartz sand (QS); gravel (G); sand - gravel - send (SGS) (Kurss, V., Stikule, A., 1997). Most of the mentioned mineral resources are used in construction and in manufacturing construction materials. However, in the past decades question about sustainable extraction and exploitation of mineral resources has been set in Latvia. Therefore, the following hypothesis is put forward - the extraction, processing and utilization of Latvian mineral resources is sustainable. The research aim is to analyse the extraction of mineral resources in Latvia as a whole and in the planning regions of Latvia. The research tasks are as follows: 1 . To discuss theoretical aspects on sustainable use of mineral resources. 2. To perform an analysis of available mineral resources in Latvia. Research methods: monographic - the information sources were analysed, compared and described; data were processed and interpret by use of statistical analysis and interpretation methods. Research novelty - the extraction and use of mineral resources is 
impossible to analyse in the resource circulation context, as it involves land use, and the mineral resources represent the basis of a circular economy and a bioeconomy.

Research results and discussion Mineral resources are minerals whose extraction and use is constrained (they are non-renewable), and their reuse is problematic, in many cases impossible, as their chemical and physical properties change during recycling (e.g. burning), which is an irreversible process (Law On Subterranean Depths, 1996). The sustainability of mineral resources could be ensured by their reasonable and efficient exploitation in the national economy (Seglins V., 2007; Lazdins A., 2016). It is important to implement a sustainable strategy on mineral resources, which is the basis of sustainable management.

The implementation of "sustainable development" means the integration of activities in the following three key areas, namely (Figure 1):

- technical and economic activities ensuring economic growth;

- ecological activities ensuring the protection of natural resources and the environment;

- social activities, meaning care for the employee at the workplace and community development in the area of mining activities (Dubinski J., 2013; Role of Government in Mineral..., 2011).

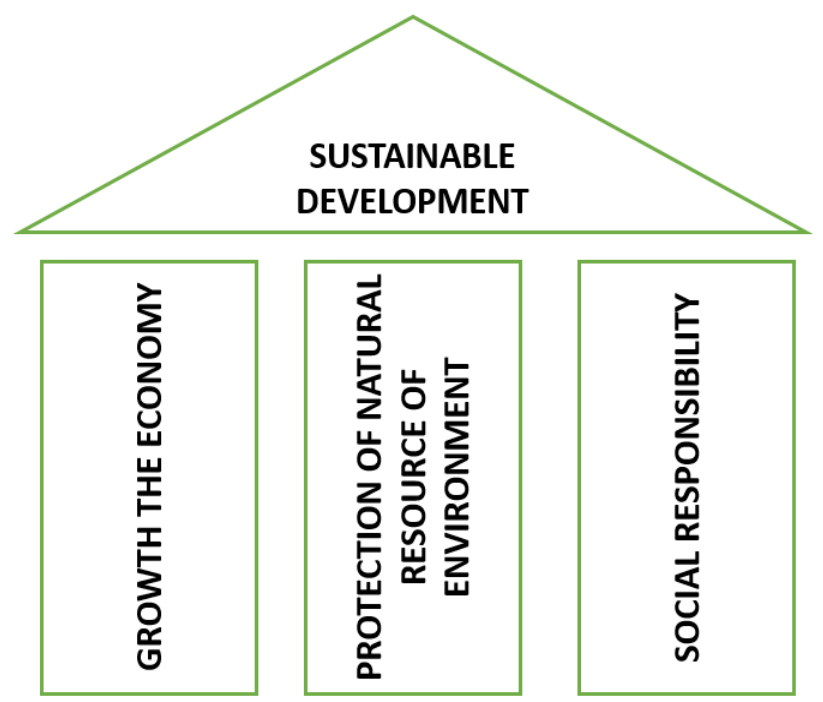

Source: authors' calculations based on Sustainable Development of Mining Mineral Resource (Dubinski J., 2013)

Fig. 1. Elements of sustainable development

The sustainable extraction and exploitation of resources ensures economic growth involving No new resources as well as environmental impact reduction and social responsibility. Ensuring the sustainability of mineral resources pertains to the model of five types of capital: natural; human; social; physical; and financial (Corder G., 2015; Dubinski J., 2013; Sustainable development..., 2013). Coordinated management of all the types of capital could contribute to sustainable resource use; it is particularly important to coordinate the extraction and exploitation of non-renewable resources (Alfsen K.H., Greaker M., 2007).

One of the most essential aspects is updated information on available mineral resources and the known and newly discovered properties of the resources as well as public education about the role of resources in personal life and public life as well as in community life (Finland's Minerals Strategy..., 2010; Developments in indicators..., 2012).

An analysis of the above opinions allows finding differences between a conventional economy and a sustainable economy - the conventional economy contributes to an increase in the consumption of goods and services, whereas the sustainable one pertains to shaping an understanding of the effects 
of growing population wishes on the opportunities for future generations to raise their standard of living.

The European Union concept of sustainable development is based on considerations representing a broad spectrum of policy activities aimed at satisfying current needs without compromising the ability of future generations to use resources and meet their needs. To achieve the goals, four interrelated pillars have been defined: economic, social, environmental as well as the pillar of globalscale governance. The priority sustainable development areas are as follows: climate change, transport, production and consumption patterns, natural resource management, public health, social exclusion and poverty and poverty reduction throughout the world (Sustainable Development in the European Union, 2013).

In Latvia, sustainable development is referred to in the strategy Latvia 2030; the basic idea is to meet the needs of the current generation by balancing the society's prosperity, environmental an economic interest while also protecting the environment and preserving diversity in nature without compromising the ability of future generations to meet their needs. The document's section Sustainable Management of Natural Values and Services defines natural capital as non-renewable natural resources: minerals (sand, gravel, clay, gypsum, dolomite) and renewable natural resources: soil, wood, energy etc. To effectively manage natural capital, it is necessary to determine the critical level of natural capital, below which it may not decrease, and set goals and targets for the preservation and restoration of natural capital. Accordingly, a comprehensive analysis of natural capital available in Latvia has to be performed, comparing the baseline situation with a reference level or a benchmark. Such an analysis would allow setting long-term requirements for sustainable management, various habitats and the areas necessary for the habitats and assessing which ecosystems need protection and which could be intensively managed (Latvija 2030, 2010).

As regards the use of underground minerals in Latvia, subterranean depths, including mineral deposits, belong to the land owner in accordance with the Civil Law. However, to contribute to sustainable resource use, the state sets its requirements in accordance with the Law on Subterranean Depths and the Law on Environmental Impact Assessment, and a compromise is achieved among the interests of the land owner, the needs of the state and environmental protection requirements based on other legal documents (Zemes dziles, [s.a.]).

Mineral resources are extracted in open quarries, removing topsoil (1-20 cm in depth) that is not useful for this purpose. Quarrying is widespread in all the five planning regions of Latvia (Kurzeme planning region - KPR, Zemgale planning region - ZPR, Riga planning region - RPR, Latgale planning region - LPR and Vidzeme planning region - VPR); the beneficiaries are natural and legal persons. The extraction of mineral resources could be started after a licence for use of subterranean depths has been acquired and a project for extraction of mineral resources has been developed (Par zemes dzilēm..., 2013).

Table 1

Mineral resource stock categories

\begin{tabular}{|l|l|}
\hline \multicolumn{1}{|c|}{ Categories } & \multicolumn{1}{c|}{ Description of categories } \\
\hline Category A & Explored reserves of mineral resources \\
\hline Category N & Estimated mineral reserves (incomplete geological exploration) \\
\hline Category P & Predicted mineral resources (stocks are valued by analogy) \\
Source: authors' calculations based on Cabinet Regulation No. $\mathbf{5 7 0}$
\end{tabular}

Source: authors' calculations based on Cabinet Regulation No. 570 
In quarrying, an important criterion is the extraction of explored mineral resources, which is a guarantee that the resources meet the needs of an enterprise to achieve its particular goals. In accordance with the Cabinet Regulation Procedures for the Extraction of Mineral Deposits (2006), mineral deposits are divided into three categories. Mineral resource licences are grated for the extraction of categories $\mathrm{A}$ and $\mathrm{N}$ mineral resources, while No licence is needed for the extraction of category $\mathrm{P}$ mineral resources because their extraction is prohibited (Table 1).

An analysis of the extraction of mineral resources for the period 2005-2017 revealed that the quantities extracted did not tend to increase significantly. After a decrease observed in 2009 (5081.63 thous. $\mathrm{m}^{3}$ ), the output of mineral resources stabilised until 2017 (Derigo izraktenu krajumu bilance, 2017).

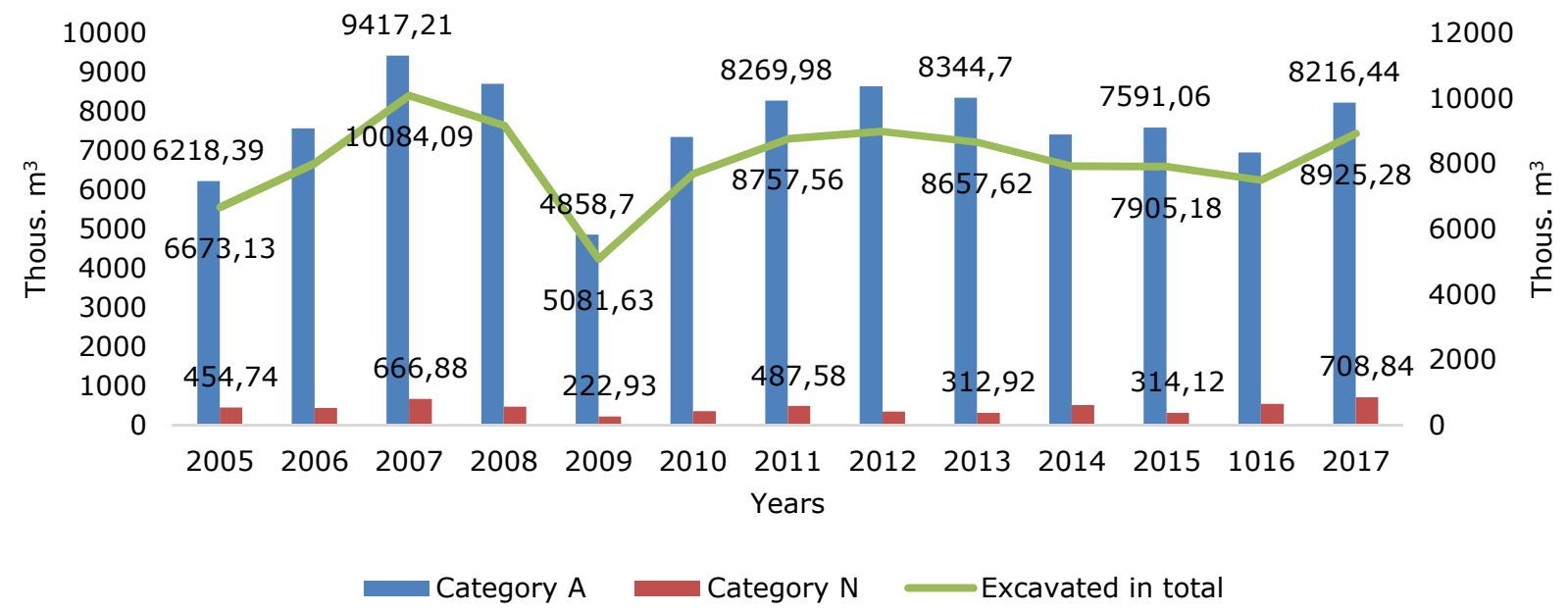

Source: authors' calculations based on LEGMC data (Derigo izraktenu krajumu bilance, 2017)

Fig. 2. Changes in the extraction of mineral resources in Latvia in 2005-2017, thousand cubic meters

In the period 2010-2017, the quantities extracted ranged from 6954.26 thous. $\mathrm{m}^{3}$ in 2016 to 8641.31 thous. $\mathrm{m}^{3}$ in 2012 (Figure 2). Overall, No considerable changes in the extraction of mineral resources of categories $\mathrm{A}$ and $\mathrm{N}$ were observed.

An analysis of the percentage breakdown of the extraction of mineral resources by planning region revealed that Riga planning region with a proportion of 27.1-37.4 \% was the largest producer of mineral resources, followed by Kurzeme planning region with a proportion of 16.5-29.1\%. 


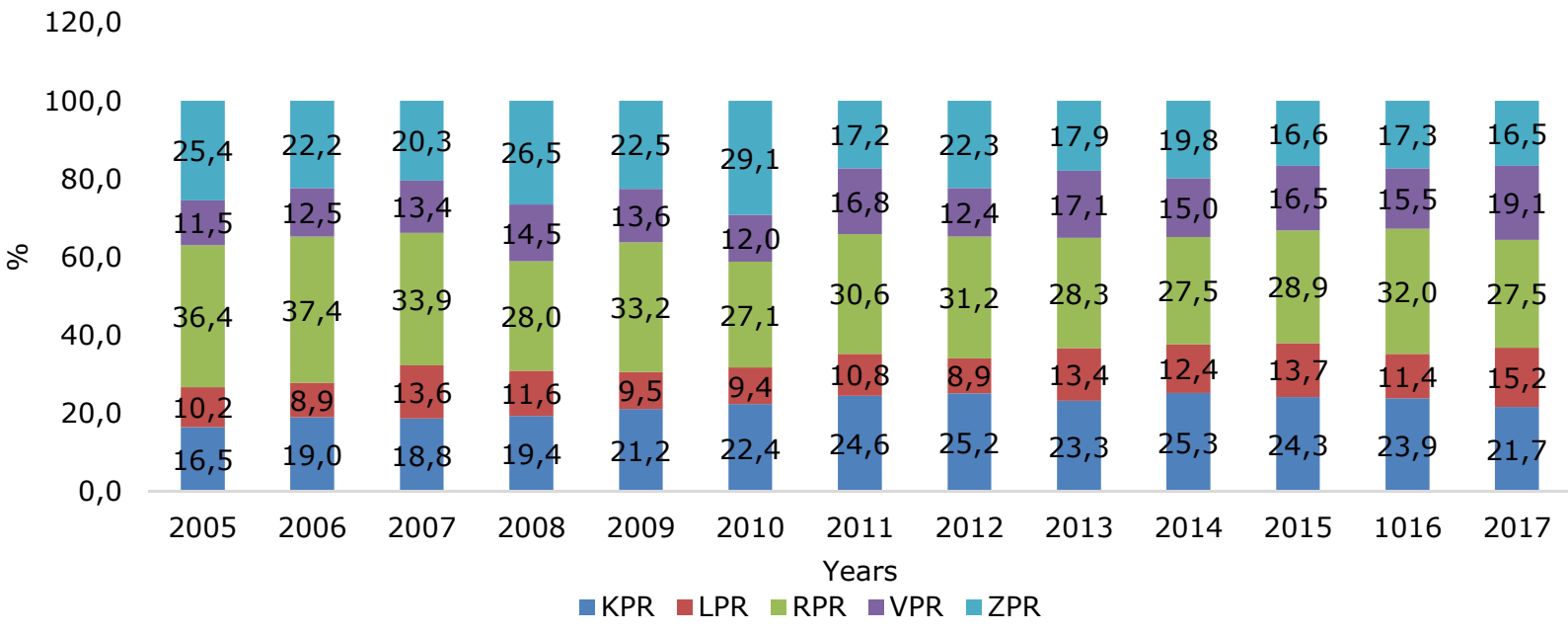

Source: authors' calculations based on LEGMC data (Derigo izraktenu krajumu bilance, 2017)

Fig. 3. Percentage breakdown of the mining of mineral resources in the planning regions of Latvia in 2005-2017

The smallest producer of mineral resources was LPR with a proportion ranging from $8.9 \%$ to $15.2 \%$ (Figure 3 ). The extraction of mineral resources was affected by a number of socio-economic factors related to the development of infrastructure objects and the population in the planning regions. Vidzeme planning region was the second smallest producer of mineral resources - the output of mineral resources ranged from 8.9 thous. $\mathrm{m}^{3}$ to 15.2 thous. $\mathrm{m}^{3}$ a year. In Zemgale planning region, the output ranged from 16.5 thous. $\mathrm{m}^{3}$ to 29.1 thous. $\mathrm{m}^{3}$ a year.

A prerequisite for sustainable exploitation of mineral resources is knowledge of the resources to be extracted and their quality. In Latvia, licences are granted for $\mathrm{N}$ category mineral resources (Table 1), which are not completely explored and there are No accurate data on their quality characteristics.

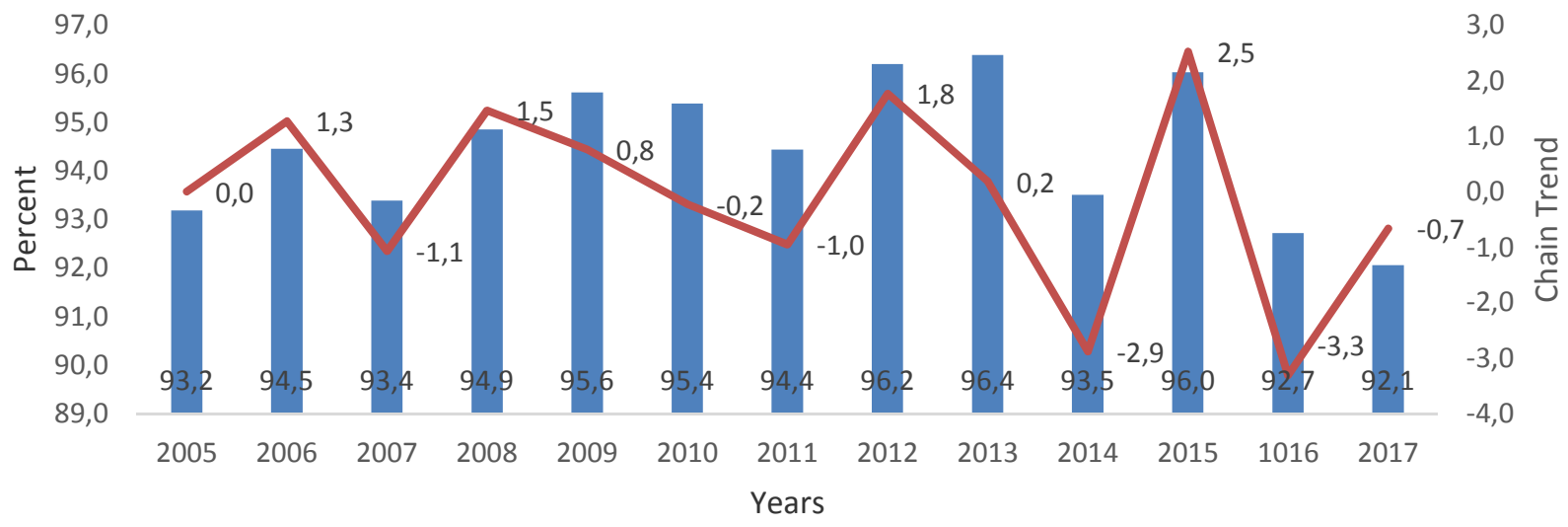

Category A Chain Trend

Source: authors' calculations based on LEGMC data (Derigo izraktenu krajumu bilance, 2017)

Fig. 4. Mining of category A mineral resources as a percentage of total and the annual growth trend in Latvia in 2005-2017

An analysis of the extraction of mineral resources by category for the period 2005-2017 revealed that the extraction of category A mineral resources dominated, ranging from $92.1 \%$ to $96.2 \%$, while the extraction of category $\mathrm{N}$ mineral resources ranged from $7.9 \%$ to $3.8 \%$ (Figure 4 ). 
No explicit trend in the extraction of category A mineral resource was observed, and only in recent years, i.e. in 2016 and 2017 the output of category $\mathrm{N}$ mineral resources considerably rose by $6.8 \%$ un $7.9 \%$, respectively, which was in line with the fast growth in construction (increase in demand for mineral resources).

An analysis of the extraction of mineral resources in per capita terms showed that the figures were relatively similar. The largest decrease was observed during the economic crisis, only in one year, i.e. in 2009.

The extraction of mineral resources is influenced by several factors: prepared projects; funds for construction and maintenance; public procurement. In general, the extraction and use of mineral resources is influenced by national economic growth, this is evidenced by the economic crisis of 2009, when resource extraction fell sharply (Figure $2 ; 5$ ).

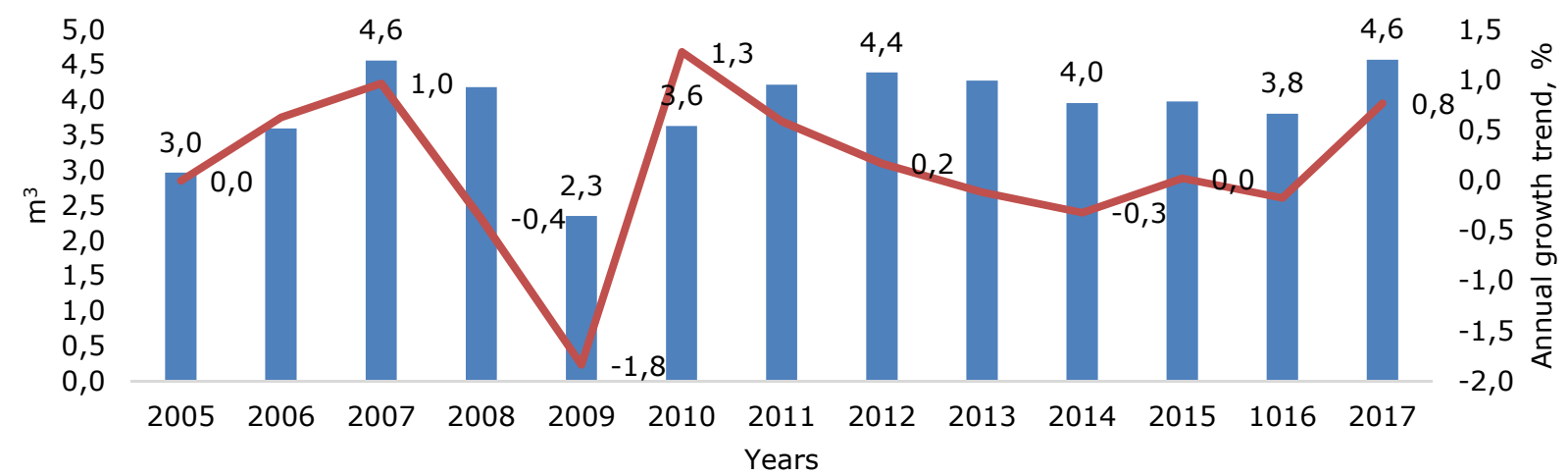

Average to per capita Chain trend

Source: authors' calculations based on LEGMC and CSB data (Derigo izraktenu krajumu bilance, 2017)

Fig. 5. Mining of mineral resources per capita in the country, the annual growth trend in 20052017, cubic meters

In 2009 in Latvia, the per-capita output of mineral deposits was $2.3 \mathrm{~m}^{3}$. In the other years of the analysis period, it ranged from $3.0 \mathrm{~m}^{3}$ to $4.6 \mathrm{~m}^{3}$ (Figure 5). No statistical data were collected on quarrying, and only professor V.Seglins has stated that the per-capita output of mineral deposits in Latvia is estimated at $1.8 \mathrm{~m}^{3}$ (Seglins V., 2007). Figure 5 shows that decreases in the population of Latvia have not affected the output of mineral resources, and only large economic shocks have made temporary effects.

The extraction, processing and consumption of mineral resources is not strongly related to economic growth in the country, yet long-term effects are possible, as the resources are used for road construction as well as the construction and maintenance of structures in the business, private and public sectors. Investments in such economic activities contribute to the sustainable use of other resources, yet such effects have not been researched in Latvia.

\section{Conclusions, proposals, recommendations}

1) The authors stress that the sustainability of mineral resources is associated with the sustainable management of extraction and exploitation of the mineral resources and public participation in making decisions on resource extraction and profit distribution, which requires higher public responsibility and leads to lower environmental impacts. With the increase in the extraction and utilization of mineral resources, public participation should increase in this process. 
2) An important prerequisite for the sustainable extraction and exploitation of mineral resources is the acquisition of new knowledge through engaging scientists in research on and public education about mineral resources and their role in public life and the life of every individual.

3) The exploitation of mineral resources in Latvia is sustainable because the resources are used in the construction of infrastructure and private and public buildings (Fig. 2), which contributes to the sustainable and rational use of other resources for economic development and growth.

4) Overall, the extraction and consumption of mineral resources in the planning regions of Latvia is done in accordance with the legal framework and controlled by accounting for the resources and granting licences for use of subterranean depths in accordance with the relevant Cabinet regulation.

5) The use of mineral resources for the construction and maintenance of infrastructure and private, commercial and public buildings affects the sustainable exploitation and maintenance of other resources, yet more research has to be done on a potential causal association between economic efficiency and sustainability for the resources.

6) Mineral extraction rates (2005 - 2017) show a steady trend, except for the mineral resource extraction rate during the 2009 economic crisis, where the direct impact of the country's economic situation is felt (Fig. 3, 5).

\section{Bibliography}

1. Auzins, A. (2016). Zemes izmantosanas novertesana un parvaldiba (Land Use Assessment and Management). Scientific monograph, Riga: RTU, 270 p.

2. Alfsen. K.H., Greaker. M. (2007). From Natural Resources and Environmental Accounting to Construction of Indicators for Sustainable Development. Journal: Ecological Economics, Volume 61, pp. 600-610.

3. Corder, D.G. (2015). Insights from Case Studies into Sustainable Design Approaches in the Minerals Industry. Journal: Minerals Engineering No 76, pp. 47-57.

4. Derigo izraktenu (buvmaterialu izejvielu, kudras un dziedniecisko dunu) krajumu bilance par 2005. - 2017. gadu (2019) (Stocks of Mineral Deposits (Construction Materials, Peat and Medicinal Mud) for the period 2005-2017. Retrieved: ttps://www.meteo.Iv/lapas/geologija/derigo-izraktenu-atradnu-registrs/derigoizraktenu-krajumu-bilance/derigo-izraktenu-krajumu-bilance?id=1472\&nid=659 pdf. Access: 10.01.2019.

5. Derigo izraktenu ieguves kartiba (2012) MK noteikumi Nr. 570 (Procedures for the Extraction of Mineral Resources. Cabinet regulation No. 570). Retrieved: https://likumi.lv/doc.php?id=251021 Access: 05.01.2019.

6. Developments in indicators: Total Material Requirement (TMR). (2000) European Environment Agency. Retrieved: http://www.eea.europa.eu/publications/signals-2000/page017.html.

7. Dubinski, J. (2013). Sustainable Development of Mining Mineral Resource. Journal of Sustainable Mining 2014, No. 12, pp. 1-6.

8. Finland's Minerals Strategy. (2010). Retrieved: https://ec.europa.eu/growth/tools-databases/eip-rawmaterials/en/system/files/ged/42 \%20FinlandsMineralsStrategy.pdf. Access: 20.01.2019.

9. Kurss, V., Stikule, A. (1997) Latvijas derigie izrakteni (Mineral Deposits in Latvia). Riga: LU. 200 p.

10. Lazdins, A. (2016). Development of the Mineral Resource Market in Latvia's Regions (Summary of the Doctoral Thesis for the Degree Dr.oec.). Jelgava. $117 \mathrm{p}$.

11. Par zemes dzilem (Law on Subterranean Depths): law of the Republic of Latvia (1996). Latvijas Vestnesis, No.87 (572), 21 May 1996.

12. Role of Government in Mineral and Energy Resources Research. The Geological Society of America. (2011). GAS. Retrieved: www.geosociety.org.

13.Seglins, V. (2007) Zemes dzilu resursi (Resources of Subterranean Depths). Riga: Publisher RaKa. 380 p.

14.Sustainable Development in the European Union. (2013) 2013 Monitoring Report of the EU Sustainable Development Strategy. Eurostat report. European Union. Retrieved:

ttps://ec.europa.eu/eurostat/documents/3217494/5760249/KS-02-13-237-EN.PDF. Access: 15.01.2019. 